\title{
Efektivitas Program Pemberdayaan Usaha Garam Rakyat di Desa Losarang, Indramayu
}

The efectivity of Salt Business Empowerment Program in Losarang, Indramayu.

\section{Santoso Budi Widiarto ${ }^{* 1}$, Musa Hubeis ${ }^{2}$ dan Komar Sumantadinata ${ }^{3}$}

\author{
${ }^{1}$ Sekretariat Direktorat Jenderal KP3K \\ Gd. Mina Bahari III It. 3 JI. Medan Merdeka Timur No. 16, Jakarta Pusat 10110 \\ ${ }^{2}$ Departemen Manajemen, Fakultas Ekonomi Manajemen, Institut Pertanian Bogor \\ Jl. Kamper, Kampus IPB Darmaga, Bogor 16680 \\ ${ }^{3}$ Departemen Budidaya Perikanan, Fakultas Perikanan dan IImu Kelautan, Institut Pertanian Bogor \\ Jl. Agatis, Kampus IPB Darmaga, Bogor 16680
}

\begin{abstract}
ABSTRAK
Sebagai negara kepulauan dengan potensi laut yang melimpah, adalah suatu ironi ketika kebutuhan garam di Indonesia tidak tercukupi. Garam adalah komoditas strategik yang dapat dengan mudah diproduksi dengan cara mengeringkan air laut. Kebijakan tentang garam telah dikeluarkan sejak zaman penjajahan Belanda. Pada tahun 2011 Pemerintah Indonesia membuat kebijakan tentang swasembada garam. Tujuan kajian ini adalah untuk menganalisis efektifitas implementasi Program Pemberdayaan Usaha Garam Rakyat (PUGAR). Metode penelitian menggunakan metode purposive dan snowball sampling, contoh diambil dari 70 responden di Losarang, Indramayu. Data dianalisis melalui analisis kualitatif, kuantitatif, analisis SWOT (Strengths, Weaknesses, Opportunities dan Threats) dan analisis MAHP (Modified Analitycal Hierarchy Process). Hasil kajian Implementasi PUGAR di Losarang, Indramayu adalah efektif. Hal tersebut diindikasikan oleh tercapainya target produksi garam dan peningkatan kesejahteraan petambak. Implementasi PUGAR menyebabkan tercapainya produktifitas lahan garam sebesar 90,34 ton/ha, peningkatan pendapatan petambak garam, terbentuknya 17 Kelompok Usaha Garam Rakyat (KUGAR) dengan jumlah anggota 170 petambak garam, memberikan inovasi teknologi dan produksi garam bermutu, serta memberikan pekerjaan pada 778 orang sebagai petambak garam, buruh pekerja dan buruh angkut. Usaha garam memiliki nilai Internal Factor Evaluation (IFE) 2,608 dan External Factor Evaluation (EFE) usaha garam 2,673. Selain itu, perhitungan kelayakan usaha $\mathrm{B} / \mathrm{C}$ ratio $>1$, profit margin usaha $31,8 \%-42,9 \%$, kesesuaian lahan garam yang dimiliki petambak, analisis kesenjangan usaha garam dan analisis titik impas. Analisis titik impas digunakan menentukan harga jual garam dalam jumlah besar dan usaha produksi garam rakyat untuk mencapai titik impas.
\end{abstract}

Kata kunci: Buruh, Garam, Pemberdayaan, Pemerintah, Petambak, PUGAR

\section{ABSTRACT}

An ironic thing that Indonesia as maritime country have insufficiency salt problem. Salt is strategic commodities that can be easily produced by evaporation of sea water and policy salts have been issued since the Dutch colonial era. In 2011 the Government of Indonesia make toward self sufficiency salt policy. This research was aimed to analyze the implementation efectivity of Salt Business Empowerment Program (Pemberdayaan Usaha Garam Rakyat or PUGAR). The research design used purposive and snowball sampling to select 70 respondents in Losarang Village at Indramayu. The data were analyzed by using Quantitative Analysis, Qualitative Analysis, SWOT and MAHP. The result showed PUGAR in Losarang, Indramayu implemented with effectiveness. This is indicated by salt production target achieved and increasing the salt farmer welfare. Implementation PUGAR make salt productivity in Losarang 90,43 ton/ha, increasing salt farmer income, empower 17 the People's Business Group Salt (Kelompok Usaha Garam Rakyat or KUGAR) with the amount of 170 salt farmers, give technological innovation and quality salt production and give job for 778 peoples as salt farmers, farm workers and transport workers. Obtained result IFE of salt bussiness is 2,608 and EFE is 2,673. Moreover the research calculate salt business feasibility that known from $\mathrm{B} / \mathrm{C}$ ratio $>1$, business profit margin, appropriate salt area owned by farmers, business gap analysis of salt and break even analysis. Break even analysis to determine the selling price of the large volume of salt and salt production business people to reach the point of no profit and no loss (break even).

Key words: Empowerment, Farmers, Government, PUGAR, Salt, Workers

\footnotetext{
$\left.{ }^{\star}\right)$ Korespondensi:

Gd. Mina Bahari III It. 3 Jl. Medan Merdeka Timur No. 16, Jakarta Pusat 10110; e-mail: santosobw@yahoo.com
} 


\section{PENDAHULUAN}

Indonesia merupakan negara kepulauan dengan luas wilayah laut 5,8 juta $\mathrm{Km}^{2}$. Luas wilayah laut ini lebih luas dari wilayah daratan yang hanya 1,9 juta $\mathrm{Km}^{2}\left(\mathrm{KKP}, 2011^{\mathrm{a}}\right)$. Potensi wilayah pesisir dan laut Indonesia menurut Kusumastanto (2003) dapat dibagi menjadi 4 bidang, yaitu (1) Sumber daya yang dapat diperbaharui, seperti perikanan (tangkap, budidaya, dan pascapanen), hutan mangrove, terumbu karang, industri bioteknologi kelautan dan pulau-pulau kecil; (2) Sumber daya yang tidak dapat diperbaharui, seperti minyak bumi dan gas, bahan tambang dan mineral lainnya, serta harta karun; (3) Energi kelautan, seperti pasang-surut, gelombang, angin, OTEC (Ocean Thermal Energy Conversion) dan (4) Jasa-jasa lingkungan, seperti pariwisata, perhubungan dan kepelabuhanan, serta penampung (penetralisir) limbah.

Garam merupakan komoditas strategik, karena selain merupakan kebutuhan pokok yang dikonsumsi manusia lebih kurang $4 \mathrm{~kg}$ per tahun juga digunakan sebagai bahan baku industri $\left(\right.$ KKP, 2011 $\left.{ }^{\mathrm{a}}\right)$. Penggunaan garam secara garis besar terbagi menjadi 3 (tiga) kelompok yaitu (1) Garam untuk konsumsi manusia, (2) Garam untuk pengasinan dan aneka pangan dan (3) Garam untuk industri. Di Indonesia, garam banyak diproduksi dengan cara menguapkan air laut pada sebidang tanah pantai dengan bantuan angin dan sinar matahari sebagai sumber energi penguapan. Produksi garam dapat dilaksanakan oleh masyarakat pesisir, tanpa diperlukan keahlian khusus. Selain garam $(\mathrm{NaCl})$, air laut dapat diolah menjadi gypsum dan garam magnesium.

Kebutuhan garam dalam negeri pada tahun 2010 mencapai sekitar 2.872.326 ton, terdiri dari kebutuhan garam industri CAP (Chlor Alkali Plant) 1.492.326 ton, garam konsumsi 720.000 ton, industri aneka pangan 465.000 ton, pengeboran minyak 135.000 ton dan lainnya 60.000 ton. Angka ini diperkirakan akan meningkat seiring dengan bertambahnya jumlah penduduk dan berkembangnya industri yang membutuhkan garam.

Kabupaten Indramayu merupakan daerah pemasok garam untuk Propinsi Jawa Barat bersama dengan Cirebon. Menurut BPS (2007) Lahan produksi garam $1.995,81 \mathrm{Ha}$ ( $54 \%$ dari luas lahan garam potensial $3.664,3 \mathrm{Ha}$ ) di Indramayu dan $1.447 \mathrm{Ha}(64 \%$ dari luas lahan garam potensial $2.251 \mathrm{Ha}$ ) di Cirebon belum bisa memenuhi kebutuhan garam di Jawa Barat. Dengan kebutuhan yang tinggi, seharusnya petambak dapat memperoleh penghasilan yang layak dari usaha garam, akan tetapi ironisnya kehidupan petambak garam di berbagai daerah di Indonesia, termasuk di Kabupaten Indramayu dihadapkan pada situasi sulit dan terpuruk serta dalam kondisi marjinal. Banyak petambak garam tidak dapat bertahan dengan pilihan usahanya, bahkan ada yang meninggalkan usahanya dan berpindah menekuni mata pencaharian lain.
Padahal bagi masyarakat pesisir, membuat garam termasuk salah salah sumber nafkah sangat penting yang diandalkan pada musim kemarau untuk memenuhi kebutuhan rumah tangganya.

Di Kabupaten Indramayu, jumlah petambak garam pemilik lahan pada tahun 1990 sebanyak 984 orang, menurun menjadi 792 orang pada tahun 2000 dan pada tahun 2005 menjadi 718 orang. Peningkatan terjadi pada jumlah petambak penggarap/buruh garap, pada tahun 2000 terdapat sebanyak 3.986 orang, pada tahun 2005 menjadi 4.793 orang dan pada tahun 2007 meningkat lagi menjadi 6.514 orang. Jumlah usaha garam di Kabupaten Indramayu juga menurun, pada tahun 1990 terdapat 29 perusahaan, pada tahun 2000 berkurang menjadi 22 perusahaan dan tahun 2005 berkurang lagi tinggal 13 perusahaan. Perusahaan garam besar seperti Sumatraco, Garindo, PT Budiono, PT Susanti Megah membangun gudang tempat penyimpanan garam di Indramayu. Tahun 2005 hanya empat perusahaan yang masih aktif di Indramayu. Jumlah ini berkurang dari tahun 1995 yang terdapat 10 perusahaan (Darmawan, 2010).

Rataan Tingkat produktivitas lahan pergaraman di Indramayu pada tahun 2000-2010 menurut data KKP $\left(2011^{\mathrm{b}}\right) 56$ ton/Ha/tahun, cukup rendah bila dibandingkan dengan Australia atau India yang dapat mencapai produktivitas 200 ton/Ha/tahun. Meskipun mempunyai lahan potensial garam yang besar, namun usaha garam rakyat berlahan kecil dan tak berlahan menyebabkan produktivitas sangat terbatas. Lahan garam bersaing dengan lahan pertanian, ataupun lahan untuk perikanan yang lain, seperti tambak udang. Rataan luas unit tambak garam rakyat $0,5-3 \mathrm{Ha}$ dengan produktivitas kurang dari 60 ton per $\mathrm{Ha}$. Untuk memproduksi garam dalam skala besar dengan mutu Standar Nasional Indonesia (SNI), diperlukan unit tambak seluas ratusan hektare dengan produktivitas \pm 80 ton per Ha. Unit tambak yang terbatas berisiko menaikkan biaya produksi dan menyulitkan capaian keseragaman standar. Untuk industri garam secara mekanis dapat dipertimbangkan pengembangannya bila terdapat lahan datar seluas $>5.000$ ha, sedangkan luas 2.000-5.000 Ha dilakukan pembuatan garam semi mekanis dan luas $<2.000$ Ha merupakan plasma inti pergaraman rakyat.

Mutu garam yang dihasilkan oleh petambak garam umumnya masih belum memenuhi SNI. Mutu garam yang dihasilkan oleh petambak memiliki kadar $\mathrm{NaCl}$ di bawah $94 \%$, sedangkan garam konsumsi memerlukan kadar $\mathrm{NaCl}>$ $94,7 \%$, garam industri memerlukan kadar $\mathrm{NaCl}$ di atas $99 \%$ (dry basis).

Sejak jaman kolonialisasi Belanda, potensi pesisir Indonesia telah dimanfaatkan dengan melakukan kebijakan monopoli pembelian dan penjualan garam. Tahun 1921 pemerintah Belanda membuat garam sendiri di atas lahan garamnya sendiri melalui Perusahaan Jawatan Regie Garam. Tahun 1937 rakyat tidak diperkenankan 
lagi membuat garam, karena kesulitan kontrol atas mutu garam rakyat dan banyaknya penjualan garam secara langsung kepada konsumen. Semua lahan garam dibeli oleh Pemerintah Belanda. Saat itu Garam mempunyai harga sama dengan gula, karena pemerintah Belanda menghendaki kesetaraan dari berbagai komoditas penting. Pemerintah Belanda merasakan manisnya sistem monopoli garam dengan mendapatkan 27.172.378 Gulden pada tahun 1931. Pada masa pendudukan Jepang, Undang-undang monopoli (Zout Monopoli Ordonantie) yang berlaku sejak 1921 dibekukan. Rakyat boleh membuat garam sendiri. Segala bentuk monopoli yang diwariskan Belanda tidak diadopsi oleh Jepang dengan alasan mengambil hati rakyat Indonesia (Rochwulaningsih, 2007).

Pada jaman kemerdekaan, Perusahaan Regie Garam dinasionalisasikan menjadi Djawatan Regie Tjandu dan Garam Republik Indonesia kemudian menjadi Perusahaan Garam dan Soda Negara pada tanggal 26 September 1952. Tahun 1961 dilakukan pemisahan menjadi Perusahan Negara (PN) Soda dan Perusahaan Negara (PN) Garam. PN Garam menjadi PT Garam pada 11 Februari 1991. Kondisi PN Garam memulai penurunan ketika tahun 1959 pemerintah mencabut monopoli garam dan melaksanakan perdagangan bebas. Tahun 1977-1993 PN Garam wajib membeli garam rakyat melalui Koperasi Unit Desa (KUD) setempat. Tahun 2004 pemerintah membuat kebijakan pelarangan impor ketika musim usaha garam dan penetapan harga dasar pembelian garam. Namun hal ini tidak berjalan efektif. PT Garam sebagai satu-satunya perusahaan negara yang memproduksi garam sendiri juga mengimpor garam 79.317 ton pada tahun 2010 lebih besar dari PT Cheetam Garam Indonesia yang hanya memasukkan garam ke Indonesia 78.331 ton, Cheetham Garam Indonesia adalah perwakilan Cheetham Salt, perusahaan garam terbesar dari Australia (Rachman dan Imran, 2011).

Selama ini distribusi dan pemasaran garam kurang efisien. Lahan garam berada di pinggir pantai yang lokasinya terpencil, dengan akses terbatas menjadi salah satu penyebab rendahnya harga yang diterima petambak garam, jauh lebih rendah dibandingkan harga di tingkat konsumen. Rendahnya harga di tingkat petambak produsen garam akan menurunkan daya tarik bagi produsen garam dalam memproduksi garam, sehingga ketergantungan Indonesia kepada garam impor akan semakin tinggi. Ketergantungan pada garam impor, khususnya untuk keperluan garam konsumsi sangat tidak mendukung ketahanan nasional karena garam adalah komoditi strategik yang secara terus menerus dibutuhkan oleh seluruh masyarakat.

Tahun 2011 pemerintah melalui Kementerian Kelautan dan Perikanan (KKP) berupaya meningkatkan produksi garam nasional dengan mendorong petambak untuk melaksanakan usaha garam melalui program Pemberdayaan Usaha Garam Rakyat (PUGAR). KKP menetapkan 9 (sembilan) Kabupaten seluas 15.033 ha sebagai sentra PUGAR, yaitu Indramayu, Cirebon, Pati, Rembang, Sampang, Sumenep, Pamekasan, Tuban dan Nagekeo. PUGAR 2011 melibatkan 14.400 petambak garam yang berasal dari 2.057 kelompok usaha garam rakyat (KUGAR).

Pemerintah berkewajiban memenuhi hak semua warga negara untuk mendapatkan pekerjaan dan penghidupan yang layak bagi kemanusiaan sesuai amanat Pasal 27 ayat 2 Undang Undang Dasar (UUD) 1945. Garam yang dihasilkan melalui pola tradisional dalam PUGAR akan dapat menyerap banyak tenaga kerja. Teknologi yang diterapkan dalam PUGAR diharapkan dapat meningkatkan produktifitas dan mutu garam sehingga dapat tercapai harga dasar garam yang ditetapkan pemerintah. Dengan begitu usaha garam dapat menjadi usaha yang layak dan dapat meningkatkan kesejahteraan petambak garam.

Penelitian ini bertujuan (1) Mengkaji efektivitas implementasi program Pemberdayaan Usaha Garam Rakyat di Desa Losarang Kecamatan Losarang Kabupaten Indramayu, (2) Mengidentifikasi faktor-faktor internal dan eksternal yang mempengaruhi keberhasilan usaha garam rakyat di Desa Losarang Kecamatan Losarang Kabupaten Indramayu, (3) Mengevaluasi kelayakan usaha tambak garam anggota kelompok usaha garam rakyat peserta program Pemberdayaan Usaha Garam Rakyat di Desa Losarang, Kecamatan Losarang, Kabupaten Indramayu.

\section{METODOLOG}

Lokasi kajian dilaksanakan di Desa Losarang, Kecamatan Losarang, Kabupaten Indramayu. Data yang digunakan meliputi data primer dan sekunder. Data primer meliputi data usaha petambak garam, keadaan sebelum dan sesudah diimplementasikannya PUGAR. Data sekunder didapatkan dari laporan dan penelitian terdahulu mengenai usaha garam rakyat, laporan dari KUGAR, dari sejumlah dinas dan instansi pemerintah seperti Kementerian Kelautan dan Perikanan, Biro Pusat Statistik, Dinas Koperasi dan UKM, Dinas Kelautan dan Perikanan dan lain-lain.

Populasinya adalah seluruh petambak garam anggota Kelompok Usaha Garam Rakyat (KUGAR) sasaran PUGAR di Desa Losarang Kecamatan Losarang Kabupaten Indramayu yang berjumlah 170 orang yang terbagi dalam 17 KUGAR. Pengambilan contoh dalam penelitian ini menggunakan metode purposive sampling dan snowball sampling.

Pengolahan dan analisis data yang dilakukan meliputi:

1. Analisis kualitatif, bertujuan untuk mengungkapkan efektivitas implementasi program 
PUGAR melalui indikator proses pencapaian tujuan PUGAR, yaitu (1) proses pembentukan KUGAR di Desa Losarang; (2) proses penyaluran Bantuan Langsung Masyarakat Pemberdayaan Usaha Garam Rakyat sesuai dengan Rencana Usaha Bersama (RUB); dan (3) proses pendampingan dan peningkatan teknologi usaha garam rakyat.

2. Analisis kuantitatif untuk mengukur enam hal pada responden, yaitu (1) Produktifitas tambak garam; (2) Pendapatan usaha garam; (3) kelayakan usaha garam; (4) Marjin keuntungan usaha garam; (5) Analisis kesenjangan (Gap analysis) dan (6) Efisiensi modal.

3. Analisis SWOT

4. Analisis Tingkat Kesejahteraan Petambak Anggota KUGAR menggunakan Analytical Hierarchy Process (AHP)

\section{HASIL DAN PEMBAHASAN}

\section{Potensi Tambak Garam Desa Losarang}

Menurut data GIS (Geographic Information System) dari survei pemetaan tambak Garam yang dilakukan Dinas Perikanan dan Kelautan Kabupaten Indramayu tahun 2010, wilayah Losarang 966,2 Ha mempunyai potensi lahan Garam 580,70 Ha $(60,1 \%)$ dimana $319,50 \mathrm{Ha}$ merupakan lahan produktif Garam dan 261,20 Ha masih dapat dikembangkan lagi. Pada musim kemarau para petambak Garam dapat dengan mudah memproduksi Garam, dengan mengandalkan sinar matahari di lahan dekat pantai dengan air laut sebagai bahan utama. Berdasarkan kepemilikan lahan, Petambak Garam di Desa Losarang dibagi menjadi dua kategori, yaitu Petambak Garam yang melaksanakan usaha Garam pada lahan milik sendiri dan petambak Garam yang melaksanakan usaha Garam pada lahan milik orang lain atau lahan Desa melalui sistem sewa dan atau bagi hasil.

Mata rantai usaha Garam rakyat di Desa Losarang terdiri lima komponen, yaitu (1) Petambak Garam, orang yang melaksanakan usaha Garam pada lahan milik sendiri dan atau pada lahan milik orang lain; (2) Buruh tambak Garam, orang yang bekerja pada tambak Garam dan dibayar oleh petambak Garam, untuk $1 \mathrm{Ha}$ lahan Garam dibutuhkan dua orang Buruh tambak yang dibayar Rp50.000-Rp70.000/orang/hari; (3) Buruh angkut hasil Garam yang di Desa Losarang disebut "pengojek", yaitu orang yang mengangkut Garam dari tambak ke pinggir jalan/gudang, dalam $1 \mathrm{Ha}$ lahan Garam dibutuhkan paling tidak 2 orang pengojek yang dibayar borongan Rp30$\mathrm{Rp} 70 / \mathrm{Kg}$, tergantung jauh dekatnya tujuan Garam diangkut; (4) Pengepul, yaitu orang yang mengumpulkan hasil usaha Garam petambak dan menjual kepada pedagang besar, usaha pengolah Garam atau usaha yang membutuhkan Garam, dan (5) Usaha pengolah Garam, dimana paling dekat adalah usaha perebusan Garam dan pembuatan Garam beryodium di Desa Santing, Kecamatan Losarang yang berbatasan dengan Desa Losarang.

Bahan baku utama Garam adalah air laut dengan kadar $\mathrm{NaCl}$ minimal $2^{\circ} \mathrm{Be}$ (dua derajat baume) yang tidak tercemar air dari daratan baik berupa air limbah rumah tangga dan industri, maupun air tawar dari aliran sungai. Dari 31 Daerah Aliran Sungai yang melalui Kabupaten Indramayu, Desa Losarang hanya dilewati 1 (satu) aliran sungai yaitu sungai Tuan, yang berjarak 3 (tiga) km dari saluran utama masuknya air laut ke tambak Garam.

Panen Garam rakyat di Desa Losarang secara normal dapat berlangsung selama 4,5 bulan dimulai pada bulan Juli sampai dengan pertengahan Nopember, dengan siklus produksi pada bulan Juli (5\%), Agustus (15\%), September (30\%), Oktober (35\%) dan Nopember (15\%). September-Oktober merupakan masa panen raya Garam saat musim kemarau tanpa hujan berlangsung.

\section{Usaha Garam Rakyat di Desa Losarang}

Usaha garam rakyat di Desa Losarang dimulai dari proses produksi sampai dengan pemasaran garam ke Pedagang/Pengepul/Industri pengolahan garam, dengan penjelasan berikut:

a. Persiapan Lahan

Persiapan lahan produksi garam dengan melakukan pengeringan lahan. Tenaga kerja pada masa persiapan lahan digunakan untuk perbaikan tanggul, saluran tambak, penyiapan areal penguapan/peminihan dan penyiapan meja kristalisasi Garam. Penyiapan areal peminihan dan meja kristal dilakukan dengan cara memasukkan air laut ke seluruh areal tambak sehingga mencapai ketingian $30 \mathrm{~cm}$. Setelah 3 hari terendam air laut, kolam peminihan dan meja kristal dikeringkan selama 1 hari.

Untuk memperoleh kualitas tanah meja kristalisasi yang baik sebelum melakukan pelepasan air tua (air laut $25^{\circ} \mathrm{Be}$ ) tanah tersebut terlebih dahulu diperlakukan "Kesap dan Guluk" (biasanya dilakukan 2 kali untuk memperoleh kualitas kekerasan tanah yang memenuhi syarat). Kesap dilakukan dengan tujuan untuk membuang lumpur dan lumut yang menempel pada permukaan tanah sedangkan Guluk bertujuan untuk mengeraskan landasan permukaan tanah.

b. Pembuatan Garam

Pembuatan dibagi dalam dua tahap, yaitu tahap penguapan sehingga air laut mencapai konsentrasi yang diinginkan, dimana cairan dengan konsentrasi tinggi, yang disebut air tua, siap mengkristal. Tempat penguapan ini disebut peminihan (evaporator). Air tua yang siap dikristalkan ditampung dalam kolam penampungan. Tahap kedua adalah tahap pengkristalan, dimana air tua dalam kolam 
penampungan akan dialirkan ke meja kristalisasi, yaitu tempat penguapan air tua, sehingga kristal Garam akan terbentuk.

\section{c. Proses Panen Garam}

Setelah 5-7 hari kristal Garam dipanen dengan cara dikais yang dalam bahasa setempat disebut "dikerik". Saat proses pengaisan, permukaan kristal Garam dalam kondisi terendam air tua sedalam $5 \mathrm{~cm}$. Garam mutu baik dihasilkan dengan kondisi seluruh permukaan kristal tenggelam tidak boleh ada yang menyembul ke permukaan, karena ketika permukaan kristal Garam menyembul kepermukaan akan terjadi kristalisasi setempat dengan cepat, sehingga akan ikut terendapkan berbagai Garam magnesium dan kalium.

Rataan jumlah meja kristal dalam lahan seluas $1 \mathrm{Ha}$ adalah 22-30 petak berukuran $3 \mathrm{~m}$ x $15 \mathrm{~m}$. Proses pengaliran air tua dilaksanakan secara bertahap 3-4 petak setiap hari, sehingga nantinya petambak akan dapat panen Garam setiap hari. Satu petak meja kristal menghasilkan 300-700 Kg Garam, sehingga saat cuaca bagus, $1 \mathrm{Ha}$ petambak akan menghasilkan 2.100-2.800 Kg Garam setiap harinya. Hasil panen Garam kemudian dibawa ke tempat pencucian Garam atau tempat pengumpulan dengan menggunakan ember. Pencucian kristal Garam dilakukan untuk meningkatkan kandungan $\mathrm{NaCl}$ dengan mengurangi/menghilangkan unsur $\mathrm{Mg}, \mathrm{Ca}$, $\mathrm{SO}_{4}$ dan kotoran lainnya.

Pencucian garam di Desa Losarang jarang dilakukan, karena menambah biaya produksi, namun tidak meningkatkan harga garam. Garam mutu rendah mempunyai harga yang sama dengan harga mutu tinggi jika dijual pada periode yang sama. Pencucian Garam biasa dilakukan oleh petambak yang akan menyimpan Garam di gudang terlebih dahulu sebelum dijual ke pasar. Pola lahan Garam secara umum di Desa Losarang dapat dilihat pada Gambar 1.

d. Pemasaran Garam

Di Desa Losarang, mutu Garam tidak berpengaruh pada harga garam. Garam mutu rendah mempunyai harga sama dengan Garam mutu bagus jika dijual pada periode sama. Kekurangan modal membuat garam tidak pernah disimpan di gudang. Petambak langsung menjual garamnya kepada pengepul, bahkan ketika Garam masih berada di tambak Garam. Pengepul menetapkan harga yang sama untuk semua harga Garam yang dibelinya. Garam mutu baik, oleh Pengepul dicampur dengan Garam mutu rendah sebelum dijual ke Pedagang besar/usaha yang membutuhkan Garam.

Harga tertinggi tahun 2010 mencapai $\mathrm{Rp} 1.750 / \mathrm{kg}$ atau 5 kali dari harga dasar Garam bermutu 1 yang ditetapkan oleh Pemerintah Rp350/kg pada saat itu. Tingginya harga Garam tahun 2010, dikarenakan kegagalan produksi Garam akibat turunnya hujan sepanjang tahun 2010.

Tahun 2011 harga Garam mencapai Rp1.200/kg pada bulan Juni 2011. Bulan Agustus harga Garam turun menjadi Rp600Rp800/kg sebelum akhirnya turun menjadi Rp350/kg pada bulan Oktober dan Nopember ketika panen raya Garam berlangsung. Kondisi ini masih lebih baik dibanding tahun 2009 ketika petambak hanya menerima Rp150Rp350 selama musim Garam.

Industri pengolahan Garam konsumsi terdekat adalah usaha perebusan Garam di Desa Santing, Kecamatan Losarang. Selain untuk memenuhi kebutuhan industri lokal, Garam Desa Losarang juga digunakan sebagai bahan baku pabrik pengolahan Garam di Bandung dan Jakarta. Selain untuk Garam konsumsi, Garam Desa Losarang juga dijual ke pabrik cat dan tekstil di Jakarta, pabrik lem dan kertas di Cikampek dan pabrik kayu lapis di Lampung. Garam di Desa Losarang juga digunakan bahan baku industri pembuatan pupuk di Cirebon dan Lampung.

\section{Karakteristik Petambak Garam}

\section{Usia}

Sebanyak 11 orang (16\%) Petambak berusia lebih dari 52 tahun, 16 orang (23\%) Petambak berusia 44-51 dan hanya 2 orang (2,9\%) responden berusia 19 dan 20 tahun, menunjukkan usaha Garam kurang diminati oleh generasi muda di Desa Losarang. Diperlukan regenerasi Petambak agar usaha Garam di Desa Losarang dapat terus dilaksanakan.

\section{Pendidikan}

Rataan tingkat pendidikan yang cukup rendah (SD 49\%) bukan merupakan kendala bagi petambak untuk melaksanakan usaha Garam. Usaha garam yang dilakukan responden banyak didasarkan pada pengetahuan dan pengalaman yang diperoleh secara tradisional turun temurun.

\section{Jumlah tanggungan keluarga}

Rataan jumlah tanggungan keluarga Petambak Garam adalah 3-4 orang. Usaha Garam akan dilaksanakan oleh petambak di Desa Losarang, jika usaha Garam dapat memberikan keuntungan untuk menghidupi petambak dan keluarganya. Berbeda dengan usaha Bandeng atau Udang, ketika petambak mengalami kerugian usaha ikan, karena turunnya harga jual ikan, maka hasil tambak ikan dapat digunakan untuk memenuhi kebutuhan makan petambak. 


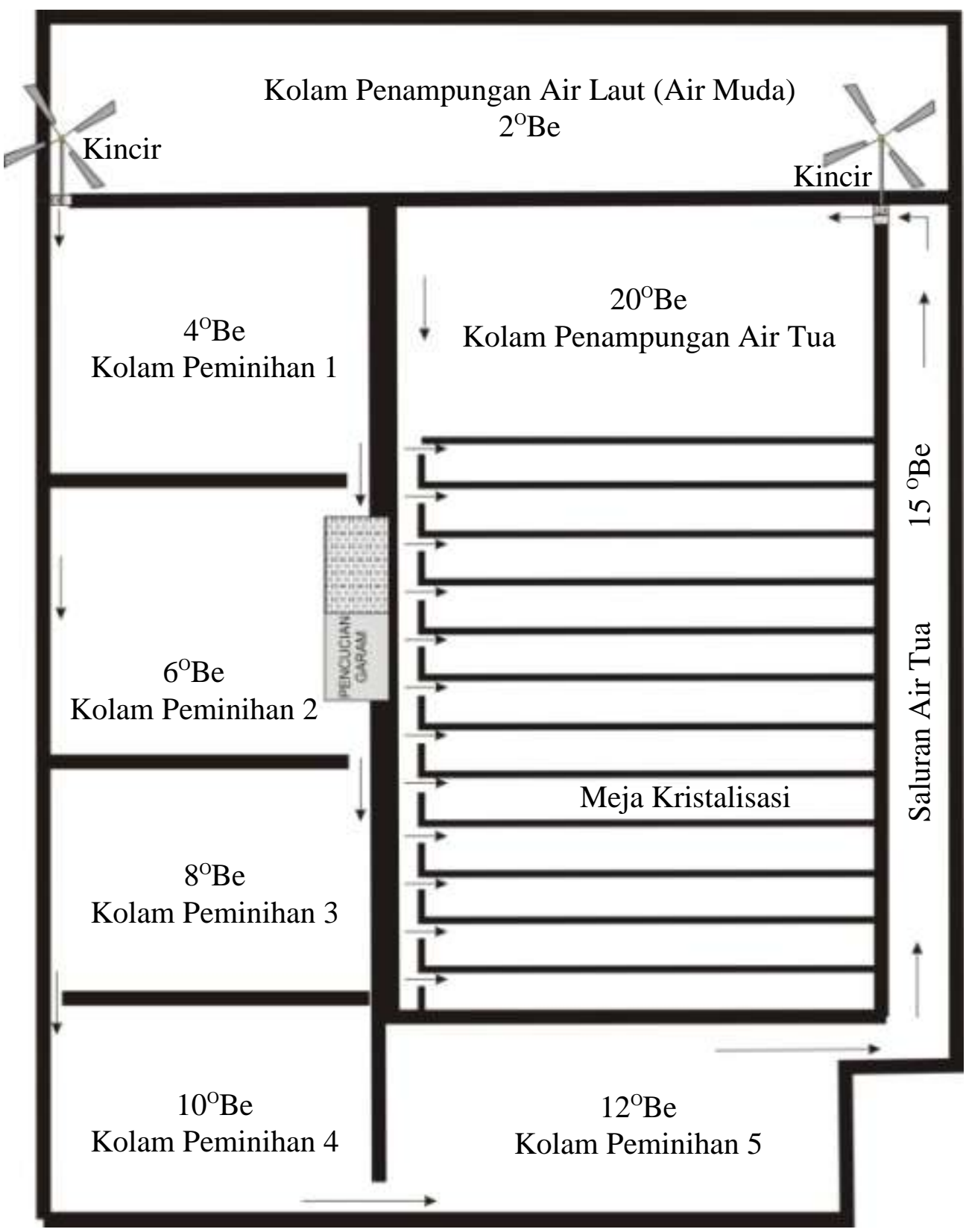

Gambar 1. Pola lahan Tambak Garam Rakyat

\section{Penggunaan tambak diluar musim Garam}

Sistem polikultur dalam pemanfaatan lahan tambak dengan menjadikan tambak Garam sebagai tambak ikan di luar musim Garam dilaksanakan 58 orang (83\%) dan hanya 12 orang $(17 \%)$ yang menjadikan lahan Garam sebagai lahan kosong di luar musim Garam.

\section{Lama bekerja di bidang usaha Garam}

Semua peserta PUGAR memiliki pengalaman usaha Garam dan telah bekerja di bidang usaha Garam minimal 1 (satu) tahun.

\section{Lama menjadi anggota kelompok usaha Garam}

Sebanyak 43 (61\%) responden baru menjadi anggota Kelompok Usaha Garam Rakyat dalam waktu 1-2 Tahun.

\section{Analisis Data Kualitatif}

\section{Proses Pembentukan KUGAR}

KUGAR sudah ada di Desa Losarang sebelum dilaksanakannya PUGAR, tetapi kurang berjalan efektif, karena KUGAR yang ada kurang memberikan manfaat bagi anggotanya. Dinas Kelautan dan Perikanan Kabupaten Indramayu melaksanakan sosialisasi PUGAR ke masyarakat, dengan dihadiri aparat Desa dan tokoh masyarakat Identifikasi Petambak Garam dan pembentukan Kelompok dilakukan oleh masyarakat didampingi oleh Tenaga Pendamping dan disetujui oleh Kepala Desa Losarang. Desa Losarang terbentuk 17 KUGAR sesuai dengan target PUGAR.

KUGAR yang terbentuk termanfaatkan untuk penyaluran bantuan langsung masyarakat dalam bentuk sarana dan prasarana usaha. Tidak adanya usaha Garam lain selain usaha Garam 
untuk menghasilkan Garam secara tradisional pada musim garam, mengakibatkan KUGAR hanya berjalan efektif selama musim garam yaitu bulan Juli-Nopember. Pembuatan Garam melalui sistem backyard ataupun usaha pengolahan Garam menjadi Garam halus dan briket belum dilakukan, meskipun sudah dilakukan fasilitasi pelatihan teknis dan non teknis Garam kepada perwakilan peserta PUGAR dari Indramayu.

\section{Proses Penyaluran BLM}

Proses penyaluran Bantuan Langsung Masyarakat (BLM) dimulai dari pembuatan Rencana Usaha Bersama yang dilaksanakan kelompok dengan panduan tenaga pendamping PUGAR. Setelah disetujui dan diketahui Kepala Desa, Rencana Usaha Bersama (RUB) disampaikan kepada team PUGAR Nasional melalui Dinas Kelautan dan Perikanan Kabupaten Indramayu. Pencairan ke kelompok dari Kantor Pelayanan Perbendaharaan Negara (KPPN) Kabupaten Indramayu langsung ke rekening kelompok masing-masing. Pencairan BLM dari rekening kelompok dilaksanakan oleh Ketua Kelompok dan Tenaga Pendamping PUGAR.

Pemanfaatan diserahkan kepada masingmasing kelompok sesuai dengan RUB yang telah diserahkan dan diverifikasi melalui Berita Acara Serah Terima BLM PUGAR yang ditandatangani oleh Kuasa Pengguna Anggaran Satker Dinas Perikanan dan Kelautan Kabupaten Indramayu dengan masing-masing.

\section{Proses pendampingan dan peningkatan tek- nologi usaha Garam rakyat}

Produksi Garam PUGAR di Indramayu mencapai 87.239 ton $(109,05 \%$ dari target KKP 80.000 ton) meskipun luas areal tambak Garam PUGAR hanya $913 \mathrm{Ha}(91,3 \%$ dari target 1000 Ha). Peningkatan produktifitas Garam tercapai dengan teknologi maduresee dan penambahan zat addiktif pada usaha Garam. Menurut Sugiyo et al (2010), metode yang paling tepat dalam pemurnian garam dapur yang bermanfaat bagi industri dan petani garam adalah dengan penambahan bahan pengikat impurities campuran dari $\mathrm{NaOH}$ dan $\mathrm{Na} 2$ dengan perbandingan $5: 5$.

Peningkatan kapasitas Petambak Garam yang meliputi kegiatan pendampingan teknis dan kelembagaan di tiga Kecamatan lokasi PUGAR tahun 2011, yaitu Kecamatan Losarang, Krangkeng dan Kandanghaur dilakukan Tenaga Pendamping bersama dengan perusahaan konsultan CV. Tria Consult. Kegiatan melalui pertemuan kelompok dan lahan percontohan. Jumlah sasaran kegiatan adalah 1.004 orang petambak Garam yang tergabung dalam 104 KUGAR.

\section{Analisis Data Kuantitatif}

\section{Produktifitas tambak Garam rakyat}

Jumlah Garam yang dihasilkan responden pada tahun 2011 pada saat diimplementasikan- nya program PUGAR adalah 13.293 ton dari luas lahan Garam $147 \mathrm{Ha}$, sehingga akan diperoleh produktifitas lahan Garam 90,43 ton/ $\mathrm{Ha}$ atau $160,6 \%$ dari rataan produktifitas lahan garam di Kecamatan Losarang tahun 2001-2010. Produktivitas lahan Garam di Desa Losarang mencapai $113 \%$ dari target produktifitas PUGAR 80 ton/Ha.

\section{Pendapatan Usaha}

Total pendapatan yang diterima oleh 70 Responden dari Garam yang dihasilkan 147 ha tambak adalah Rp2.624.945.500. Musim Garam 2011 memberikan penghasilan Rp2.749.087.100 kepada 708 orang pekerja di tambak Garam yang terdiri dari Buruh tambak dan Buruh angkut.

\section{Kelayakan Usaha}

Nilai $B / C$ ratio usaha Garam di Desa Losarang $>1$, dengan nilai terendah 1,15 dan tertinggi 3,16 . Dari nilai $\mathrm{B} / \mathrm{C}$ ratio tersebut dapat disimpulkan usaha Garam di Desa Losarang layak untuk dilaksanakan.

BEP produksi paling rendah adalah 34.479 $\mathrm{kg}$, artinya jika produksi kurang dari $34.479 \mathrm{~kg}$, maka petambak akan mengalami kerugian. BEP harga paling tinggi Rp369,85 artinya jika harga Garam $/ \mathrm{Kg}$ yang diterima petambak kurang dari Rp369,85, maka Petambak akan mengalami kerugian, karena biaya untuk menghasilkan Garam lebih besar daripada hasil penjualan Garam.

Nilai kebutuhan Petambak Garam diambil dari Upah Minimum Kabupaten Indramayu pada tahun 2011 sebesar Rp944.190. Luas tambak minimal yang layak adalah $0,24 \mathrm{Ha}$, artinya dengan produktifitas lahan dan harga jual Garam tinggi, dari lahan garam 0,24 Ha petambak dapat menghasilkan Garam senilai Rp11.330.280 (Rp994.190 x 12 bulan) yang dapat digunakan untuk memenuhi kebutuhan hidup minimal petambak di Desa Losarang selama 1 tahun. Luas tambak maksimal yang dimiliki petambak untuk memenuhi kebutuhan minimum yang layak adalah $3,10 \mathrm{Ha}$, artinya diperlukan $3,10 \mathrm{Ha}$ untuk menghasilkan Garam senilai Rp11.330.280 (Rp994.190 x 12 bulan).

Kebutuhan lahan garam yang lebih luas untuk memenuhi kebutuhan hidup minimal petambak garam dikarenakan rendahnya produktifitas tambak Garam dan harga yang diterima Petambak. Dengan produktifitas 90 ton/Ha dan keuntungan Petambak Rp150 diperlukan luas lahan $0,84 \mathrm{Ha}$ untuk memenuhi kebutuhan hidup minimal Petambak selama 1 tahun.

\section{Marjin Keuntungan (Profit Margin)}

Marjin keuntungan dimiliki 53\% responden adalah $31,8 \%-42,9 \%$ artinya dari total penjualan Garam yang dihasilkan, Petambak memperoleh keuntungan $31,8 \%-42,9 \%$ dari hasil penjualan. Hanya 3 (tiga) responden (4\%) yang memiliki marjin keuntungan kurang dari $20,7 \%$.

Marjin keuntungan yang besar, menunjukkan semakin besar kemampuan Petambak untuk 
memperoleh keuntungan dari penjualan Garam yang dihasilkannya. Marjin keuntungan yang kecil dari usaha garam di Desa Losarang dikarenakan petambak menjual garam dengan mutu rendah tanpa memberikan nilai tambah pada produk yang dihasilkannya. Dengan posisi tawar yang lemah, petambak akan dapat mudah ditekan Pedagang/Pengepul untuk memperkecil marjin keuntungan yang diperoleh oleh petambak selaku produsen, dan memperbesar marjin keuntungan yang diperoleh Pedagang/Pengepul.

\section{Analisa Kesenjangan (Gap Analysis)}

Analisis kesenjangan dengan nilai 56 , artinya konsumen harus membayar harga 56 kali dari keuntungan yang diterima petambak. Keuntungan terbesar diperoleh produsen garam beryodium yang mengolah garam dari petambak menjadi garam beryodium siap konsumsi.

\section{Efisiensi Modal}

Efisiensi modal 49,6\%-84,3\% diperoleh 37 orang (53\%) Petambak di Desa Losarang dan hanya 11 orang (15\%) yang usahanya memiliki efisiensi modal lebih dari 84,3\%. Dengan efisiensi modal $100 \%$, artinya petambak telah memiliki modal untuk melaksanakan usaha Garam pada musim berikutnya. Efisiensi modal dibawah $100 \%$ artinya usaha Garam yang dilaksanakan tidak memberikan keuntungan yang cukup untuk melaksanakan usaha Garam pada musim berikutnya.

\section{Analisis SWOT} Identifikasi Faktor Kekuatan, Kelemahan,
Peluang dan Ancaman

1. Kekuatan

i. Pekerja berpengalaman

ii. Belum ada substitusi produk Garam

iii. Peralatan produksi sederhana

iv. Bahan baku produksi melimpah

v. Kesesuaian potensi lahan
2. Kelemahan

i. Usaha Garam hanya 4 bulan dalam setahun

ii. Luas Lahan yang sempit, sehingga kurang menguntungkan untuk intensifikasi usaha

iii. Posisi tawar petambak Garam lemah

iv. Kelemahan modal

v. Kurangnya sarana dan prasarana

3. Peluang

i. Kebijakan pemerintah mendukung usaha Garam rakyat

ii. Potensi lahan Garam besar

iii. Bantuan Langsung Masyarakat (BLM)

iv. Tenaga pendamping teknis dan kelembagaan

v. Penggunaan teknik maduresee dan ramsol

4. Ancaman
i. Cuaca
ii. Harga tidak stabil
iii. Impor Garam
iv. Tengkulak
v. Alih tenaga kerja

\section{IFE dan EFE}

1. Identifikasi matriks IFE

Faktor-faktor kekuatan dan kelemahan pada usaha Garam Rakyat di Desa Losarang, Kecamatan Losarang, Kabupaten Indramayu dapat dilihat pada Tabel 1.

2. Identifikasi matriks EFE

Faktor-faktor peluang dan ancaman pada usaha Garam Rakyat di Desa Losarang, Kecamatan Losarang Kabupaten Indramayu dapat dilihat pada Tabel 2.

3. Analisis Matriks IE

Total nilai matriks IFE 2,608 dan nilai matriks EFE 2,673. Dengan demikian posisi usaha Garam Rakyat di Desa Losarang terletak pada sel V. Strategi yang sesuai untuk diterapkan pada sel ini adalah penetrasi pasar dan pengembangan produk.

Tabel 1. Matriks IFE dari usaha Garam Rakyat di Desa Losarang, Kecamatan Losarang, Kabupaten Indramayu

\begin{tabular}{lccc}
\hline \multicolumn{1}{c}{ Faktor Strategik Internal } & $\begin{array}{c}\text { Bobot } \\
(\mathbf{a})\end{array}$ & $\begin{array}{c}\text { Rating } \\
(\mathbf{b})\end{array}$ & $\begin{array}{c}\text { Bobot x Rating } \\
(\mathbf{a ~ x ~ b )}\end{array}$ \\
\hline $\begin{array}{l}\text { Kekuatan } \\
\text { 1. Belum ada substitusi produk Garam }\end{array}$ & 0,145 & 3,8 & \\
2. Pekerja berpengalaman & 0,113 & 4,0 & 0,5510 \\
3. Bahan baku produksi melimpah & 0,088 & 3,4 & 0,4520 \\
4. Kesesuaian Potensi Lahan & 0,083 & 3,6 & 0,2992 \\
5. Peralatan Produksi Sederhana & 0,088 & 3,2 & 0,2988 \\
Kelemahan & & & \\
1. Kurangnya Sarana dan Prasarana & 0,079 & 1,4 & 0,111 \\
2. Posisi tawar Petambak Garam lemah & 0,077 & 1,6 & 0,123 \\
3. Kelemahan Modal & 0,143 & 1,0 & 0,143 \\
4. Luas lahan sempit kurang & & & \\
$\quad$ menguntungkan untuk intensifikasi & 0,076 & 2,0 & 0,152 \\
$\quad$ usaha & & & \\
5. Usaha Garam hanya 4 bulan setahun & 0,109 & 1,8 & 0,196 \\
\hline$\quad$ Jumlah & 1,000 & & 2,608 \\
\hline
\end{tabular}


Tabel 2. Matriks EFE dari usaha Garam Rakyat di Desa Losarang, Kecamatan Losarang, Kabupaten Indramayu

\begin{tabular}{|c|c|c|c|}
\hline Faktor Strategik Eksternal & $\begin{array}{l}\text { Bobot } \\
\text { (a) }\end{array}$ & $\begin{array}{l}\text { Rating } \\
\text { (b) }\end{array}$ & $\begin{array}{c}\text { Bobot x Rating } \\
(\mathrm{a} \times \mathrm{x})\end{array}$ \\
\hline \multicolumn{4}{|l|}{ Peluang } \\
\hline 1. Kebijakan Pemerintah & 0,174 & 3,8 & 0,661 \\
\hline 2. Potensi Lahan Garam Besar & 0,130 & 3,6 & 0,468 \\
\hline 3. Bantuan Langsung Masyarakat & 0,100 & 4,0 & 0,400 \\
\hline 4. Tenaga Pendamping Teknis dan Kelembagaan & 0,086 & 3,4 & 0,292 \\
\hline $\begin{array}{l}\text { 5. Penggunaan Teknologi Maduresee dan Ramsol } \\
\text { Ancaman }\end{array}$ & 0,064 & 3,2 & 0,205 \\
\hline 1. Harga Tidak Stabil & 0,079 & 1,20 & 0,095 \\
\hline 2. Alih Tenaga Kerja & 0,064 & 1,80 & 0,115 \\
\hline 3. Cuaca & 0,130 & 1,00 & 0,130 \\
\hline 4. Tengkulak & 0,075 & 2,00 & 0,150 \\
\hline 5. Impor Garam & 0,098 & 1,60 & 0,157 \\
\hline Jumlah & 1,000 & & 2,673 \\
\hline
\end{tabular}

\section{Formulasi Strategi}

Berdasarkan identifikasi faktor strategik internal dan eksternal yang diperoleh, selanjutnya ditetapkan alternatif strategi dengan menggunakan matriks SWOT (Gambar 2). Formulasi strategi pengembangan usaha Garam rakyat di desa Losarang dapat dirumuskan sebagai berikut:

1. Strategi $\mathrm{S}-\mathrm{O}$ (kombinasi $\mathrm{S}_{1}-\mathrm{S}_{5}$ dengan $\mathrm{O}_{1}-\mathrm{O}_{5}$ )

i. Meningkatkan produktivitas untuk meningkatkan keuntungan

ii. Memperluas jaringan pemasaran

2. Strategi $\mathrm{W}-\mathrm{O}$ (kombinasi $\mathrm{W}_{1}-\mathrm{W}_{5}$ dengan $\mathrm{O}_{1}$ -

$\mathrm{O}_{5}$ )

i. Menetapkan kawasan khusus usaha Garam

ii. Memanfaatkan jasa perbankan untuk pengembangan usaha

iii. Meningkatkan pengetahuan manajemen usaha

3. Strategi $\mathrm{W}-\mathrm{T}$ (kombinasi $\mathrm{W}_{1}-\mathrm{W}_{5}$ dengan $\mathrm{T}_{1}-\mathrm{T}_{5}$ )

i. Memasyarakatkan usaha Garam backyard

ii. Meningkatkan teknologi produksi dan penyimpanan produk

4. Analisis tingkat kesejahteraan petambak Garam

Dengan nilai > 80, maka implementasi

PUGAR di Desa Losarang, Kecamatan Losarang Kabupaten Indramayu sangat efektif untuk meningkatkan kesejahteraan Petambak lebih dari $15 \%$ sesuai target PUGAR. Peningkatan kesejahteraan, karena implementasi PUGAR ini diperoleh dari peningkatan pendapatan 68 responden $(97,14 \%)$, penyerapan tenaga kerja 65 responden $(92,86 \%)$ dan terendah diperoleh dari perluasan kesempatan berusaha 9 responden $(12,86 \%)$.

\section{Implikasi Hasil Kajian}

\section{Implikasi teknis}

Secara teknis PUGAR berimplikasi pada perbaikan sarana dan prasarana usaha Garam di Desa Losarang. Dengan sarana dan prasarana yang baik, Petambak dapat melaksanakan usaha Garam. KKP mengimplementasikan program $\mathrm{Pe}$ ningkatan mutu Garam rakyat melalui pembuatan unit pengolahan Garam berkapasitas 4 ton Garam

\section{Implikasi ekonomi}

Implementasi PUGAR dan penetapan harga dasar Garam oleh Kementerian Perdagangan dapat meningkatkan rataan harga Garam diterima Petambak pada tahun 2011 Rp500 (100\% dibandingkan tahun 2009) dengan harga terendah Rp350 dan tertinggi Rp1.200. Perbaikan supply chain management akan memaksimalkan nilai Garam yang dihasilkan secara keseluruhan, sehingga tidak terjadi gap analisys yang tinggi antara harga Garam dari Petambak dan harga Garam yang harus dibayar oleh konsumen. Penerapan manajemen nilai (value management) dilakukan untuk meningkatkan efektivitas dan efisiensi usaha Garam.

\section{Implikasi sosial}

Perhatian dan dukungan pemerintah melalui kebijakan usaha Garam yang berpihak kepada rakyat akan menumbuhkan keyakinan dan semangat Petambak untuk melaksanakan usaha Garam. Menurut Haryatno (2012), perhatian dan bantuan pemerintah tersebut juga diharapkan dapat memperbaiki teknologi pembuatan garam yang masih tradisional dan sederhana.

Semangat masyarakat untuk melaksanakan usaha Garam akan melahirkan inovasi dari masyarakat untuk meningkatkan mutu dan produktifitas usaha Garam. Zat tambahan yang ditemukan petambak dari Desa Santing, Kecamatan Losarang adalah wujud inovasi dari petambak untuk menghasilkan Garam bermutu dan meningkatkan produktivitas. Teknik maduresee yang berkembang di lingkungan petambak Garam tradisional, karena sempitnya areal lahan, diperbaiki dengan teknologi ulir yang juga ditemukan Petambak dari Cirebon. Produksi Garam di Desa Losarang juga memberikan lapangan kerja bagi Buruh tambak, Buruh angkut, pedagang Garam dan menumbuhkan usaha Garam beryodium. 


\begin{tabular}{|c|c|c|}
\hline Faktor Internal & $\begin{array}{l}\quad \text { KEKUATAN (S) } \\
\text { S1. Pekerja berpengalaman } \\
\text { S2. Belum ada substitusi } \\
\text { produk Garam } \\
\text { S3. Peralatan produksi } \\
\text { sederhana } \\
\text { S4. Bahan baku produk } \\
\text { melimpah } \\
\text { S5. Kesesuaian potensi lahan }\end{array}$ & $\begin{array}{l}\quad \text { KELEMAHAN (W) } \\
\text { W1. Produksi Garam hanya } 4 \\
\text { bulan setahun } \\
\text { W2. Luas lahan sempit } \\
\text { W3. Posisi tawar Petambak } \\
\text { W4. Keterbatasan Modal } \\
\text { W5. Kurangnya sarana dan } \\
\text { prasarana }\end{array}$ \\
\hline $\begin{array}{ll}\text { PELUANG (O) } \\
\text { O1. Kebijakan Pemerintah } \\
\text { O2. Potensi lahan Garam } \\
\text { besar } \\
\text { O3. Bantuan Langsung } \\
\text { Masyarakat } \\
\text { O4. Tenaga pendamping } \\
\text { teknis dan } \\
\text { kelembagaan }\end{array}$ & \begin{tabular}{ll}
\multicolumn{1}{c}{ Strategi SO } \\
1. \\
Meningkatkan produktivitas \\
$(\mathrm{O} 1, \mathrm{O} 2, \mathrm{O} 3 ; \mathrm{S} 1, \mathrm{~S} 3, \mathrm{~S} 4, \mathrm{~S} 5)$ \\
2. \\
Memperluas jaringan \\
pemasaran (O1,O2,O4; S2, \\
$\mathrm{S} 4, \mathrm{~S} 5)$
\end{tabular} & $\begin{array}{l}\text { Strategi WO } \\
\text { 1. Menetapkan kawasan khusus } \\
\text { Usaha Garam (O1,O2;W1,W2, } \\
\text { W5) } \\
\text { 2. Memanfaatkan jasa perbankan } \\
\text { untuk pengembangan usaha } \\
\text { (O1,O2,O4; W4,W5) } \\
\text { 3. Meningkatkan pengetahuan } \\
\text { manajemen usaha (O1,O4; } \\
\text { W2,W3) }\end{array}$ \\
\hline $\begin{array}{l}\quad \text { ANCAMAN }(\mathbf{T}) \\
\text { T1. Cuaca } \\
\text { T2. Harga tidak stabil } \\
\text { T3. Impor Garam } \\
\text { T4. Tengkulak } \\
\text { T5. Alih fungsi lahan Garam }\end{array}$ & \begin{tabular}{ll}
\multicolumn{1}{c}{ Strategi ST } \\
1. & Menetapkan Pola Usaha \\
& Garam (S1, S5;T1,T5) \\
2. & Meningkatkan mutu produk \\
(S1,S2,S4; T2,T3) \\
3. & penguatan anggota \\
& Petambak dengan kelompok \\
(T2,T3,T4; S1,S5)
\end{tabular} & \begin{tabular}{ll}
\multicolumn{1}{c}{ Strategi WT } \\
1. \\
Memasyarakatkan usaha \\
Garam backyard \\
$(\mathrm{T} 1, \mathrm{~T} 5 ; \mathrm{W} 1, \mathrm{~W} 2)$ \\
2. & Meningkatkan teknologi \\
produksi dan penyimpanan \\
produk (T1,T2,T4; W2,W4,W5)
\end{tabular} \\
\hline
\end{tabular}

Keterangan : - (Oi; $\mathrm{Si})$ atau $(\mathrm{Oi} ; \mathrm{Wi})$ atau $(\mathrm{Ti} ; \mathrm{Si})$ atau $(\mathrm{Ti} ; \mathrm{Wi})$ menunjukkan kombinasi faktor eksternal dengan internal dalam menghasilkan pilihan strategi.

- $\mathrm{i}=1,2, \ldots \ldots . . \mathrm{n}$

Gambar 2. Matriks analisis SWOT usaha garam rakyat

\section{KESIMPULAN}

1. PUGAR di Desa Losarang, Kecamatan, Losarang Kabupaten Indramayu dapat diimplementasikan secara efektif oleh KUGAR melalui peningkatan produktivitas lahan garam petambak, pencapaian target produksi garam PUGAR dan peningkatan kesejahteraan petambak $15 \%$ sesuai target PUGAR. RUB KUGAR berjalan efektif selama musim Garam berlangsung, tetapi musim garam selesai, tidak memiliki RUB.

2. Kekuatan yang paling berpengaruh dari usaha Garam adalah belum ada substitusi produk garam, sehingga akan selalu ada kebutuhan Garam sepanjang tahun. Dengan adanya kebutuhan ini, petambak selaku produsen seharusnya memiliki kekuatan besar mempengaruhi pasar garam, namun dengan kelemahan usaha garam rakyat masih tradisonal, mengandalkan cuaca dan kurangnya sarana dan prasarana usaha, petambak hanya dapat menghasilkan garam bermutu rendah dalam waktu terbatas. Kebijakan pemerintah yang meliputi Kebijakan produksi melalui PUGAR, penetapan harga dasar garam dan larangan impor garam merupakan peluang terbesar yang dimiliki Petambak Garam dalam mengatasi ancaman usaha Garam.

3. Usaha garam anggota KUGAR peserta program PUGAR di Desa Losarang layak untuk dilaksanakan dengan nilai $\mathrm{B} / \mathrm{C}$ ratio > 1. Dengan produktifitas lahan yang tinggi dan harga yang menguntungkan, usaha garam yang berlangsung \pm 4 bulan, dapat digunakan untuk memenuhi kebutuhan hidup minimal, petambak selama 1 tahun. Usaha garam memiliki profit margin rendah dan analisis kesenjangan tinggi menunjukkan petambak dapat meningkatkan nilai jual garam melalui supply chain management dan management value.

\section{DAFTAR PUSTAKA}

Badan Pusat Statistik (BPS). 2007. Indramayu Dalam Angka 2007. BPS, Indramayu.

Darmawan, W. 2010. Potret Kehidupan SosialEkonomi Di Kabupaten Indramayu (Tinjauan Historis Tahun 1970-2007). Jurnal Penelitian 
Pendidikan Abmas Volume 11 No 1 April 2010. Universitas Pendidikan Indonesia, Bandung.

Haryatno, D. P. 2012. Kajian Strategi Adaptasi Budaya Petani Garam. Jurnal Komunitas, 4(2):191-199.

Kementerian Kelautan dan Perikanan (KKP). $2011^{\mathrm{a}}$. Kelautan dan Perikanan dalam Angka 2010. Pusat Data Statistik dan Informasi (Pusdatin), Kementerian Kelautan dan Perikanan, Jakarta.

$2011^{\mathrm{b}}$. Pedoman Pelaksanaan Pemberdayaan Usaha Garam Rakyat. Direktorat Pemberdayaan Masyarakat Pesisir dan Pengembangan Usaha (PMPPU) Kementerian Kelautan dan Perikanan, Jakarta.
Kusumastanto, T. 2003. Ocean Policy dalam Membangun Negeri Bahari di Era Otonomi Daerah. Gramedia Pustaka Utama, Jakarta.

Rachman, AJ dan Imran, M. 2011. Petambak Garam Indonesia dalam Kepungan Kebijakan dan Modal. Inninawa dan Indonesia Berdikari, Makasar.

Rochwulaningsih, Y. 2007. Petani Garam dalam Jeratan Kapitalisme, Analisis Kasus Petani Garam di Rembang Jawa Tengah. Jurnal Masyarakat, Kebudayaan dan Politik Tahun XX No 3 Juli 2007. Universitas Airlangga, Surabaya.

Sugiyo, W, Jumaeri dan C, Kurniawan. 2010. Perbandingan Penggunaan $\mathrm{NaOH}-\mathrm{NaH}$ dengan $\mathrm{NaOH}-\mathrm{Na}_{2}$ sebagai Bahan Pengikat Impurities pada Pemurnian Garam Dapur. Jurnal Sainteknol, 8(1):57-68. 